\title{
PENDEKATAN MUSICARIUM SEBAGAI RUANG PENGHUBUNG KOMUNITAS MUSIK DAN RUANG KOMUNAL DENGAN PENDEKATAN THIRD PLACE
}

\author{
Rommy Gunawan ${ }^{1)}$, Doddy Yuono ${ }^{21}$ \\ 1) Program Studi S1 Arsitektur, Fakultas Teknik, Universitas Tarumanagara, gunawanrommy@gmail.com \\ 2) Program Studi S1 Arsitektur, Fakultas Teknik, Universitas Tarumanagara, doddyy@ft.untar.ac.id
}

\begin{abstract}
Abstrak
Jakarta sebagai ibukota memiliki daya tarik tersendiri sehingga banyak pendatang dari luar daerah yang datang untuk berbagai aktivitas. Hal ini menyebabkan kepadatan kota menjadi salah satu ancaman bagi kehidupan kota. Banyaknya aktivitas membuat ruang dalam kota menjadi sempit dan juga kemacetan yang sangat parah membuat tingkat stress penduduk kota menjadi tinggi. Rutinitas penduduk ibukota menjadi sangat monoton yaitu hanya melakukan kegiatan kerja kemudian setelah itu maka mereka langsung pulang ke rumahnya masing-masing. Hal ini membuat manusia yang tadinya sebagai makhluk sosial menjadi makluk yang personal karena berada dilingkup yang sama terus menerus, bertemu orang yang sama terus menerus sehingga kemonotonan penduduk menjadi tinggi dan tingkat stress juga meningkat. Program yang diusung merupakan hasil dari analisis data dan lapangan, dimana kebutuhan akan rekreasi dalam leisure itu sangat diperlukan yaitu tempat berkumpul. Jenis proyek yang diputuskan untuk didesain adalah tempat berkumpul dengan pendekatan third place untuk komunitas serta pengadaan ruang-ruang komunal sebagai ruang pertemuan dengan orang baru sehingga kemonotonan akan hilang. Setelah dilakukan penelitian dan pencarian data, didapati kawasan Tanjung Duren menjadi lokasi 'Musicarium: Ruang Penghubung Komunitas Musik' sebagai suatu wadah hiburan musik dan juga tempat kuliner dengan menghadirkan ruang-ruang komunal. Konsep proyek ini adalah menghadirkan ruang-ruang yang sifatnya terbuka agar transparan sehingga proyek ini menjadi sebuah arsitektur yang nyaman bagi semua kalangan.
\end{abstract}

Kata kunci: hiburan; komunitas; tempat berkumpul

\begin{abstract}
Jakarta as the capital has its own charm so that many migrants from outside the area come for various activities. This causes the density of the city to be one threat to city life. The number of activities makes the city spaces become narrow and also very severe congestion makes the stress level of city residents become high. The routine of the inhabitants of the capital becomes very monotonous, that is, they only carry out work activities, then after that, they immediately return to their homes. This makes humans who were previously social creatures into personal beings because they are in the same environment over and over again, meeting the same people continuously so that the population's monotony is high and stress levels are also increasing. The program carried out is the result of data and field analysis, where the need for recreation in leisure is indispensable, namely a hangout. The type of project that was decided to be designed was a hangout place with a third place approach based on community and the provision of communal spaces as meeting rooms with new people so that the motives would disappear. After research and data searching, the Tanjung Duren area was found to be the location of the 'Musicarium: Connecting Space for Music Communities' as a place for musical entertainment and also a culinary place by presenting communal spaces. The concept of this project is to present spaces that are open to be transparent so that this project becomes an architecture that is comfortable for all people.
\end{abstract}

Keywords: community; entertainment; hangout 


\section{PENDAHULUAN}

\section{Latar Belakang}

Jakarta sebagai sebuah ibukota didalamnya terdiri dari beragam aktifitas yang padat serta mobilitas yang tinggi menyebabkan munculnya berbagai permasalahan bagi masyarakat kota. Contoh paling relevan yaitu tentang tingkat stress yang dialami masyarakat kota meningkat akibat kejenuhan akan beraktifitas yang dilakukan setiap hari secara monoton dan berulang. Terlebih lagi bahwa Jakarta sangat padat baik dengan adanya bangunan tinggi serta pengguna jalanan yang membuat kemacetan sehingga tingkat lelah secara mental itu lebih terasa. Kegiatan yang dilakukan dalam kota cenderung hanya pada rumah tinggal dan tempat kerja sehingga ruang lingkup yang menjadi rutinitas hanya sebatas orang yang sama. Persoalan tersebut dapat diatas dengan adanya sebuah tempat rekreasi yang dapat mengisi leisure menjadi lebih refreshing untuk masyarakat kota Jakarta. Hal ini didasari atas teori George Torkildsen dalam bukunya yang berjudul leisure and recreation mengatakan pentingnya leisure sebagai waktu luang untuk beristirahat dan menghibur diri yang selanjutnya disebut sebagai third place. Aktivitas leisure ini secara umum menurut Hartoto J. (1983:40) yaitu olahraga, pertunjukkan seni, hobi, dan musik yang menurutnya merupakan aktivitas penghilang stress paling banyak diminati oleh manusia. Keberadaan tempat berkumpul atau yang sering kita sebut dengan "tongkrongan" merupakan aspek penting bagi penghilang stress masyarakat kota.

Coffee shop, café, maupun bar merupakan contoh tempat berkumpul yang baik. Pengunjung yang beragam meluangkan waktu untuk sekedar minum dan menikmati alunan musik untuk mencairkan suasana setelah beraktifitas. Berkumpul, berbincang, makan, minum, ataupun menonton pertunjukkan baik itu pertandingan bola ataupun pertunjukkan musik secara langsung (live music performance) menjadi aktifitas yang ada di tempat berkumpul tersebut. Suasana yang demikian yang membuat tempat-tempat seperti ini menjadi sangat diminati bagi kebanyakan orang sebagai destinasi untuk berkumpul. Disamping untuk meredakan kejenuhan, mereka melepas kemonotonan dengan bertemu orang baru di tempat tersebut sembari mendengarkan alunan musik yang menstimulasi otak untuk meredakan stress. Pertunjukkan live music juga memberikan warna tersendiri bagi pengunjung dibanding hanya mendengarkan musik dari perangkat keras dalam café. Dengan live music pengunjung bisa ikut merasakan alunan musik secara langsung dari pemusiknya dan ikut mengekspresikan dirinya untuk ikut hanyut dalam sebuah melodi musik. Oleh karena itu diperlukan wadah yang menampung berbagai macam penduduk yaitu Musicarium Ruang Penghubung Komunitas Musik yang nantinya disebut sebagai tempat berkumpul yang sifatnya lebih ke arah musik dan kuliner. Sehingga bukan hanya sebuah tempat berkumpul pada umumnya yang menikmati makanan atau minuman melainkan adanya unsur pertunjukkan musik secara langsung agar suasana lebih berwarna.

\section{Permasalahan}

Dalam proyek Musicarium Ruang Penghubung Komunitas Musik ini, terdapat permasalahan yang perlu dijawab dan dikaji sehingga pencapaian proyek dapat tepat guna, diantaranya yaitu pertama, tempat berkumpul seperti apa yang diperlukan di Jakarta? Kedua, mengapa Tanjung Duren terpilih sebagai lokasi tapak untuk proyek third place ini? Ketiga, bagaimana caranya untuk dapat menyesuaikan program yang dipilih dengan tapak agar muncul hubungan timbal balik positif dengan lingkungannya sehingga menjadi tempat yang berguna bagi kawasan? Keempat, bagaimana pendekatan dalam mendesain bentukkan bangunan agar menonjolkan nilai sebagai sarana rekreatif dengan pendekatan konsep third place serta tema musik dalam sebuah tampilan yang membangkitkan rasa kagum dan berkesan serta menunjukkan ekspresi bangunan ini? 


\section{Tujuan Proyek}

Adapun tujuan dari penulisan ini adalah memberikan contoh pengalaman yang berbeda dalam penyediaan tempat berkumpul yang bersifat musik dan kuliner sebagai sebuah tempat yang menghibur sekaligus tempat berkumpul dan juga sebagai sarana untuk komunitas musik Tanjung Duren dapat berkarya dan memiliki panggung sekaligus menghibur pengunjung menggantikan destinasi berkumpul yang saat ini ke mall menjadi ke tempat yang lebih banyak ruang komunal dengan kesempatan berinteraksinya lebih tinggi. Serta menyediakan tempat berkumpul di Tanjung Duren sebagai destinasi wisata kuliner dengan impovisasi pengadaan live music performance dan ruang-ruang komunal yang disediakan sebagai tempat yang benarbenar untuk kumpul. Alasan ini dikarenakan musik sangat penting bagi hiburan manusia terlebih lagi di kafe atau restoran menurut Informasi (2018).

\section{Batasan Proyek}

Proyek berada di kawasan Jakarta Barat yaitu Jl. Lontar Raya, Tanjung Duren Utara, Kecamatan Grogol petamburan, Jakarta Barat di atas tapak berukuran $6.599 \mathrm{~m}^{2}$ yang berada di tengah-tengah Tanjung Duren sebagai pusat kawasannya. Didukung dengan bangunan sekitar yang menjadikannya sebagai titik tengah kawasan yaitu adanya pemukiman penduduk sebagai sasaran pengunjungnya, gedung olahraga, sarana keagamaan, sarana pendidikan, sarana perbelanjaan, sarana pemerintahan daerah, dan sarana kulineran. Proyek ini memiliki besaran tingkat pelayanan kelurahan. Perencanaan ditekankan pada masalah panggung utama beserta ruangan untuk komunitas musik lainnya dan orientasinya dengan resto dan lainnya dengan mempertimbangkan aktivitas dan pelaku sehingga dapat menjadi wadah yang komunikatif. Fasilitas yang disediakan dibagi menjadi sub-sub berikut yaitu hall komunal, stage performance, ruang komunitas, food and beverages, galeri, mini perpustakaan, store, retail tenant, dan stage outdoor.

\section{KAJIAN LITERATUR}

\section{Open Architecture}

Jika diartikan dari terjemahan berarti Arsitektur yang terbuka yang penulis artikan sebagai sebuah arsitektur yang terbuka akan perkembangan baik secara desain maupun terbuka bagi semua orang yang melakukan berbagai aktivitas di dalamnya. Arsitektur yang terbuka ini berarti arsitektur yang mampu hidup dengan kondisi saat ini yaitu multi fungsi.

\section{Third place}

Third place adalah tempat penting yang merupakan kebutuhan masyarakat, selain dari rumah ( $1^{\text {st }}$ place $)$ maupun tempat kerjanya $\left(2^{\text {nd }}\right.$ place $)$. Third place adalah tempat public yang netral, sebagai tempat alternative, siapapun dapat kesana, dan dapat digunakan berbagai aktivitas, dan dapat digunakan siapa saja. Third place ini sangat penting dalam membangun komunitas yang baik menurut Mary F. Casey (2009).

Menurut Ray Oldenburg (1989) di dalam bukunya The great good place, Third place adalah a place to be di luar tempat bekerja (second place) dan tempat tinggal (first place). Karakteristik third place adalah terbuka terhadap semua jenis kelamin, usia, dan status;Terjangkau secara ekonomi;Mudah dijangkau; Selalu tersedia; Sederhana; Penyetara sosial; Netral; Suasana yang ceria; Interaksi adalah kegiatan utama; $A$ place to be.

\section{Musicarium}

Musicarium tersusun dari 2 kata yaitu Music dan Arium. Music adalah musik sedangkan Arium adalah istilah a place for atau jika dibahasa Indonesia artinya tempat untuk bermusik.

\section{Community}

Pengertian Komunitas Menurut Kertajaya Hermawan (2008), adalah sekelompok orang yang saling peduli satu sama lain lebih dari yang seharusnya, dimana dalam sebuah komunitas terjadi relasi pribadi yang erat antar para anggota komunitas tersebut karena adanya kesamaan interest atau values. 


\section{HUB}

Merupakan ruang publik tempat pusat kegiatan yang dapat berupa sekolah, pusat lingkungan atau ruang public lain yang menawarkan layanan bersama dan terpadu seperti pendidikan, kesehatan, layanan sosial, dll. (community hubs website) Café

Kafe berasal dari bahasa perancis yaitu café, yang mempunyai arti sebetulnya (minuman) kopi. Kafe merupakan suatu tipe restoran yang biasanya menyediakan tempat duduk didalam dan diluar ruangan. Kafe tidak menyajikan makanan berat namun lebih berfokus pada menu makanan ringan seperti kue, roti, dan sup. Untuk minuman biasanya disajikan the, kopi, juice, serta susu cokela, serta minuman yang semacam coktil. Kafe pertama kali muncul dibarat. Istilah kafe paling umum dijumpai di Negara Perancis yang kemudian diadopsi oleh kota-kota di inggris pada akhir abad ke-19. Istilah kafe (café) berasal dari kata coffe yang berarti kopi. Kafe merupakan tempat yang cocok untuk bersantai, melepas kepenatan, serta bertemu dengan kerabat.

\section{Stage}

Stage jika ditranslate artinya adalah panggung. Panggung adalah tempat berlangsungnya sebuah pertunjukan dimana interaksi antara kerja penulis lakon, sutradara, dan aktor ditampilkan di hadapan penonton. Di atas panggung inilah semua laku lakon disajikan dengan maksud agar penonton menangkap maksud cerita yang ditampilkan. Untuk menyampaikan maksud tersebut pekerja teater mengolah dan menata panggung sedemikian rupa untuk mencapai maksud yang dinginkan. Seperti telah disebutkan di atas bahwa banyak sekali jenis panggung tetapi dewasa ini hanya tiga jenis panggung yang sering digunakan. Ketiganya adalah panggung proscenium, panggung thrust, dan panggung arena.

Dengan memahami bentuk dari masingmasing panggung inilah, penata panggung dapat merancangkan karyanya berdasar lakon yang akan disajikan dengan baik. Tata panggung disebut juga dengan istilah scenery (tata dekorasi). Gambaran tempat kejadian lakon diwujudkan oleh tata panggung dalam pementasan. Tidak hanya sekedar dekorasi (hiasan) semata, tetapi segala tata letak perabot atau piranti yang akan digunakan oleh aktor disediakan oleh penata panggung. Penataan panggung disesuaikan dengan tuntutan cerita, kehendak artistik sutradara, dan panggung tempat pementasan dilaksanakan. Oleh karena itu, sebelum melaksanakan penataan panggung seorang penata panggung perlu mempelajari panggung pertunjukan. (Santoso, 2008)

\section{METODE}

Metode yang digunakan pada penelitian ini yaitu dengan studi literatur, studi lapangan, dan menganalisa. Studi literatur diterapkan dengan cara melakukan kajian teori serta mengumpulkan dan menganalisis beberapa preseden proyek yang terkait sehingga menghasilkan dasar-dasar program perencanaan dan perancangan arsitektural. Didapatkan program utama yaitu komunitas musik dan tempat berkumpul kuliner (makan, minum). Studi lapangan dengan melakukan pengamatan langsung ke lapangan melihat fakta-fakta dan data lapangan sehingga dapat menghasilkan potensi maupun strategi desain. Kemudian Menganalisa berbagai data yang telah dikumpulkan dan dikaji sehingga menghasilkan konsep bangunan, zoning, program ruang, sirkulasi dan lain sebagainya (Tjahjono, Gunawan (2000).

Mendapatkan kesimpulan bahwa bangunan didesain berdasarkan kriteria tempat berkumpul yaitu keterbukaan dan perkumpulan. Oleh karena itu, bangunan ini akan didesain dengan menerapkan keberadaan ruang-ruang komunal baik itu berupa panggung ataupun lobi sebagai ruang pertemuan bagi pengunjung. Desain bangunan ini secara keseluruhan bersifat sentris pada program utama yaitu open resto dengan orientasi ke bagian tengah yang terdapat panggung live music sebagai pertunjukkan yang terbuka. Terdapat juga bagian komunitas musik yang berupa sebuah zona bagi keperluan mereka dan terdapat panggung musik tertutup sebagai salah satu program utama yang lebih ekslusif. Panggung tertutup ini dapat dialihfungsikan sebagai ruang pertemuan baik untuk acara keagamaan pada pagi hari ataupun 
dapat dijadikan sebagai teater film saat tidak ada pameran musik sehingga bangunan dapat dimanfaatkan secara efektif (cross-programs). Bangunan ini juga terdapat ruangan dengan mix-programs yaitu mini perpustakaan, ruang listening dan working space yang digabung menjadi satu ruang sehingga suasananya berbeda dan lebih berbaur. Untuk keseluruhan, bangunan ini memiliki center di tengah yang berupa panggung dan juga tangga-tangga akses menuju lantai berikutnya.

\section{DISKUSI DAN HASIL}

Musicarium Ruang Penghubung Komunitas Musik di Tanjung Duren ini terletak di Jl. Lontar Raya, Tanjung Duren Utara, Kecamatan Grogol petamburan, Jakarta Barat di atas tapak berukuran $6.599 \mathrm{~m}^{2}$. Konsep bangunan ini adalah sebagai sebuah tempat berkumpul dengan penyediaan musik yang dipadukan dengan kuliner di kawasan Tanjung Duren.

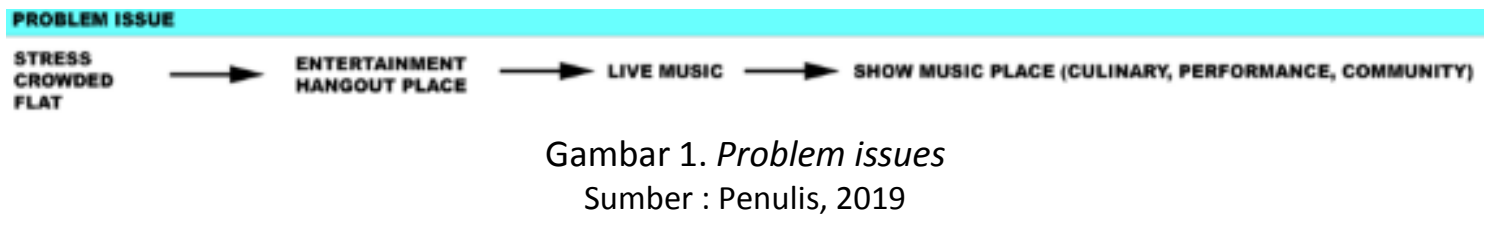

Dengan masalah mengenai stress dan kejenuhan maka dibutuhkan tempat hangout yang menghibur dan rencanakan dengan pengadaan live music dari komunitas musik di Tanjung Duren serta kuliner yang merupakan identitas dari kawasan Tanjung Duren ini sendiri.

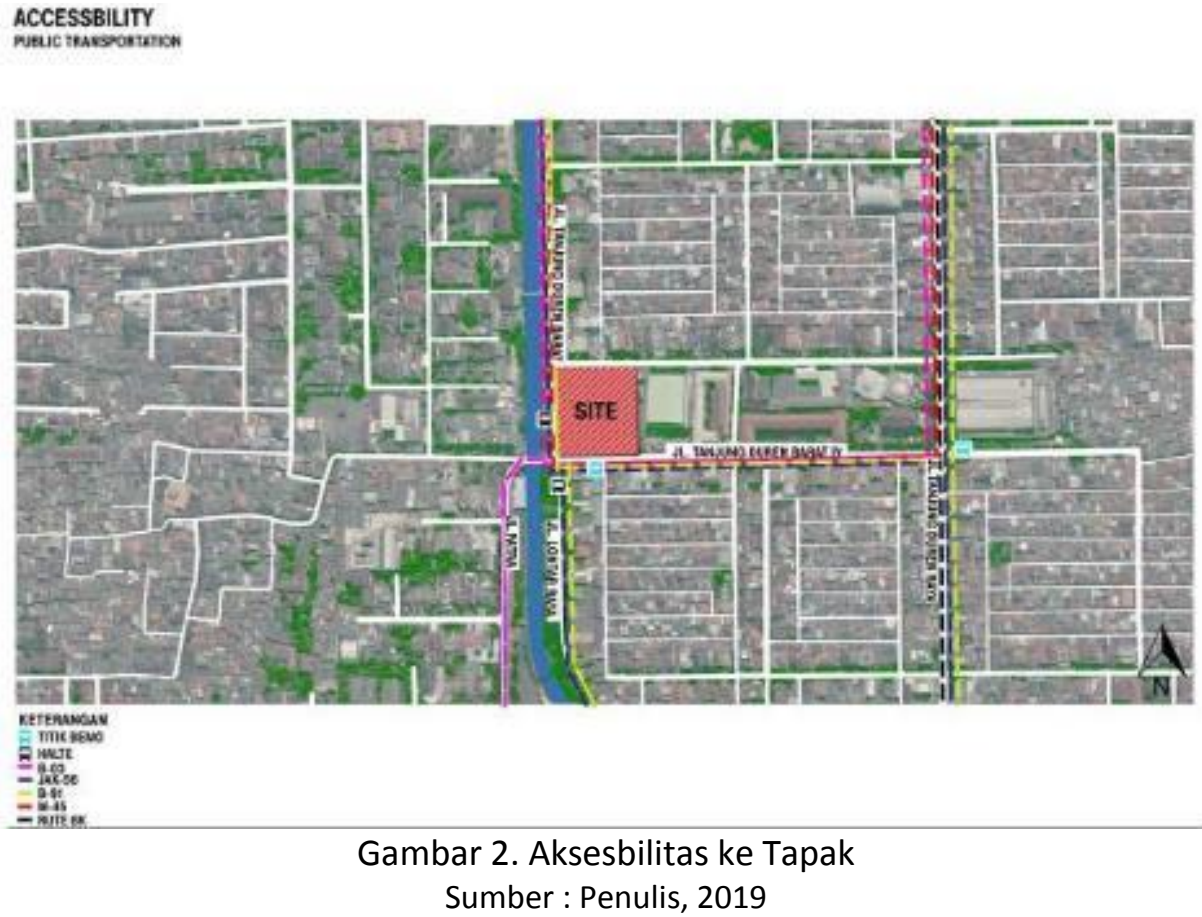

Site berada di tanah hook yang dikelilingi oleh jalan JI. Tanjung Duren Barat, Jl. Tanjung Duren Barat III, dan JI. Tanjung Duren Barat IV. Site dapat diakses dengan transportasi publik berupa bus, mini-bus, maupun angkot karena dilintasi berbagai rute transportasi publik seperti yang dijabarkan pada gambar 2. mengenai aksesbilitas ke tapak. Dengan potensi transportasi publik ini maka pencapaian menuju tapak tidak bermasalah. 


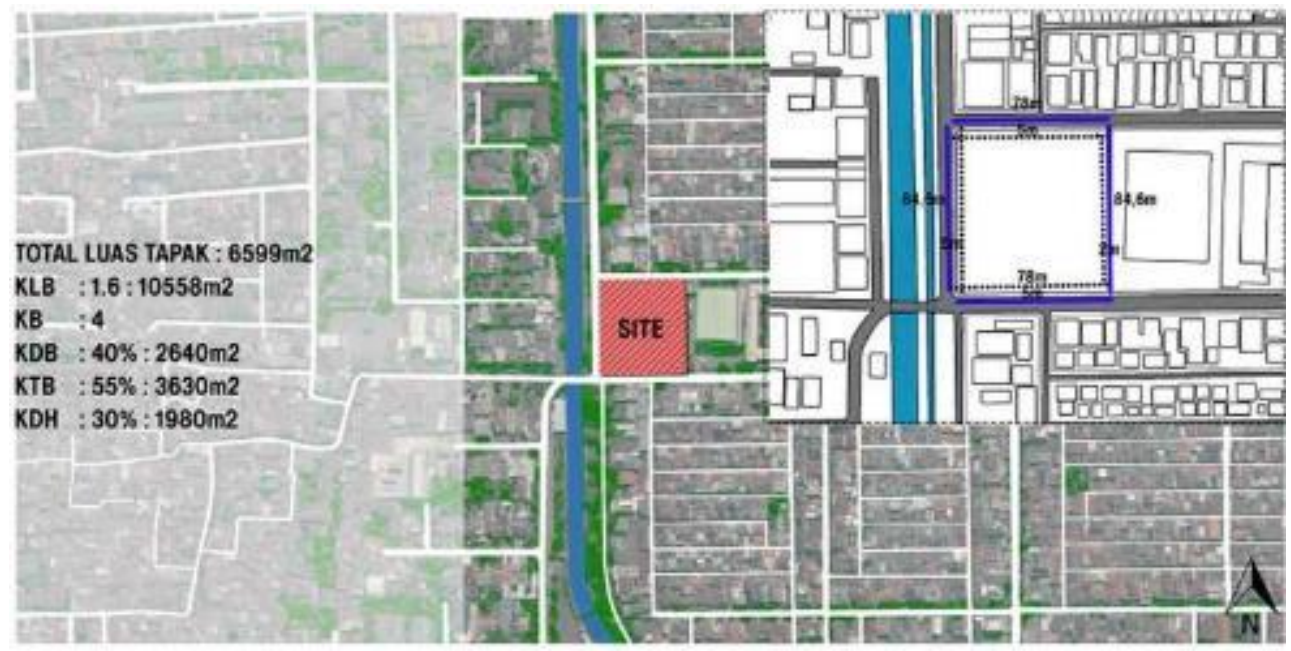

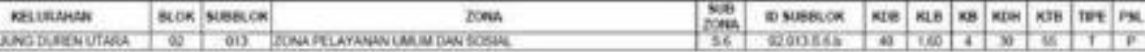

Gambar 3. Data Tapak

Sumber : Penulis, 2019

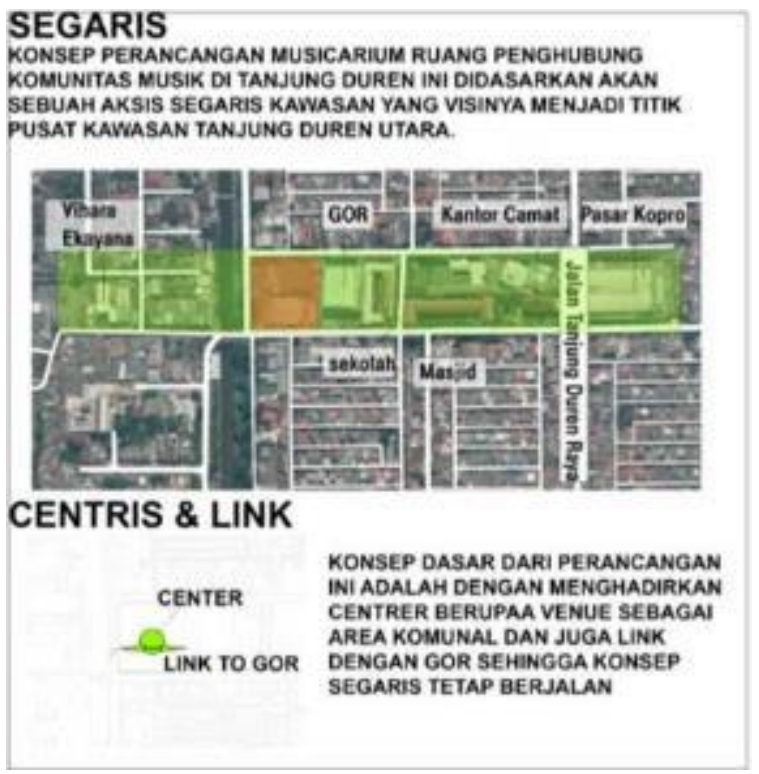

Gambar 4. Konsep kawasan

Sumber : Penulis, 2019

Konsep awal dari penentuan site adalah untuk menjadi pusat kawasan yang terintegrasi secara program dan beragam sehingga benar-benar dapat disebut sebagai sebuah pusat kawasan Tanjung Duren. Di titik ini merupakan titik ideal karena berbagai fungsi yang beragam sehingga direncanakan sarana hiburan dan tempat berkumpul agar menjadi sebuah garis yang lengkap. Diharapkan dengan adanya proyek ini, garis ini menjadi sebuah pusat dari kegiatan Tanjung Duren dan menjadi destinasi wisata kuliner dan hiburan baru yang dapat dipertimbangkan di kawasan. Site juga berada di samping GOR tanjung duren sehingga direncanakan adanya link agar terintegrasi dengan penggung GOR. Pada site sendiri, konsep besarnya yaitu centris yang memusat dengan adanya sebuah venue/ panggung sebagai area komunal dan sebuah gambaran akan konsep third place yang mana menjadi sebuah tempat berbaur antar kumpulan orang yang datang. 


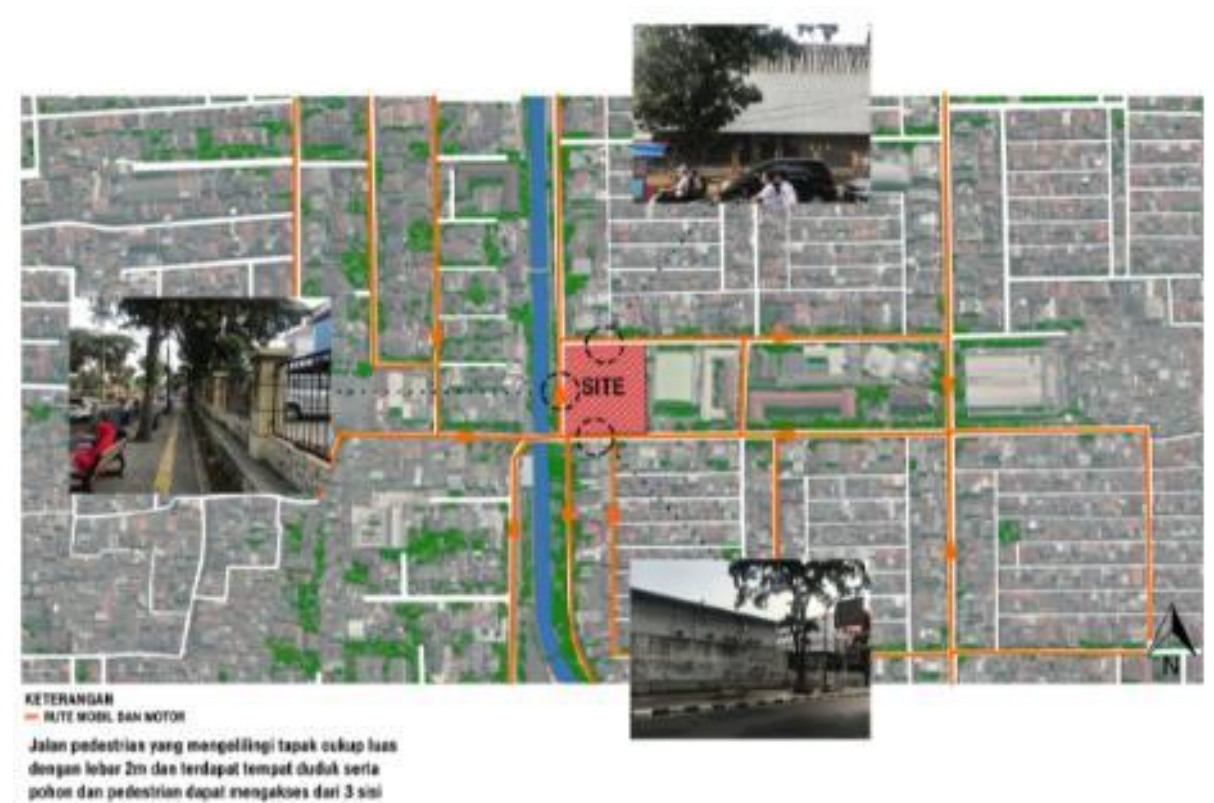

Gambar 5. Rute Mobil,Motor dan Pedestrian Sumber : Penulis, 2019

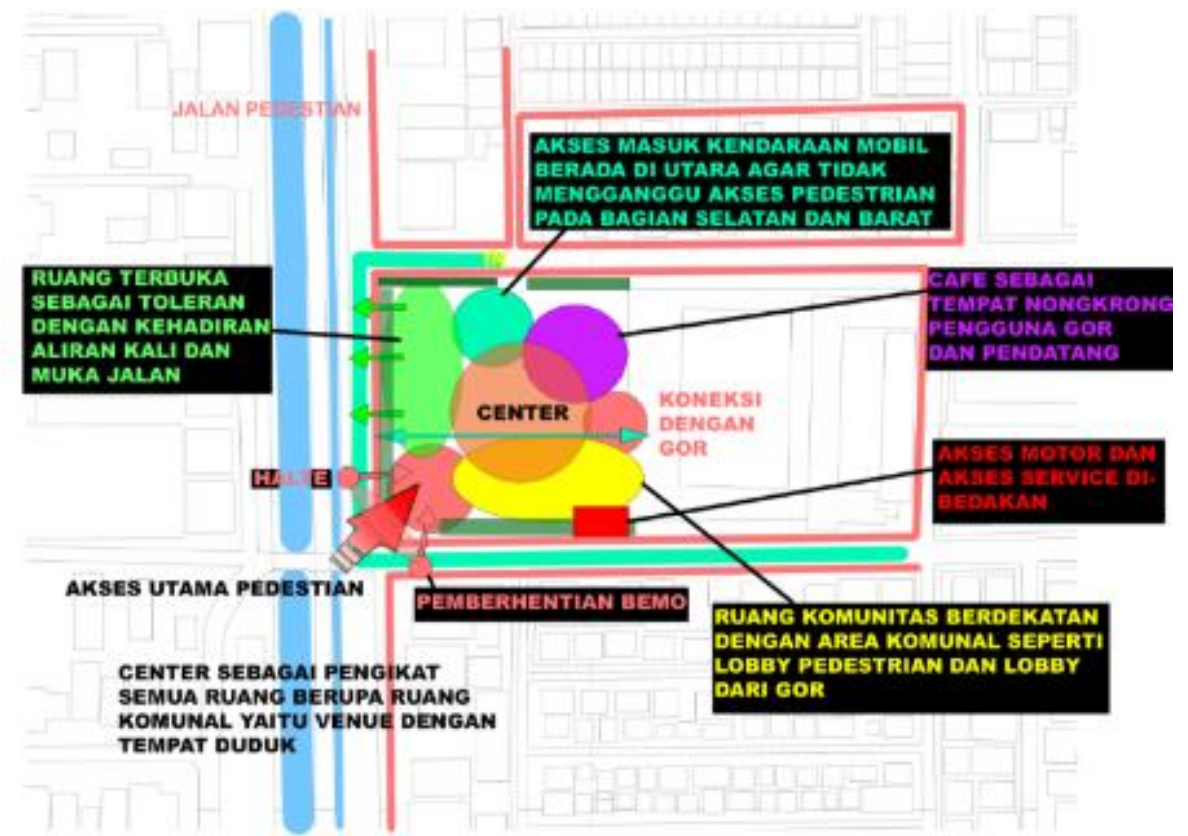

Gambar 6. Zoning Site in-out

Sumber : Penulis, 2019

Akses utama menuju site berada pada sisi barat tapak yaitu di Jl. Tanjung Duren Barat dan JI. Lontar Raya. Akses utama yang dimaksutkan adalah akses pedestrian dikarenakan terdapat halte di sebrang jalan sisi barat ini sehingga entrance utama berada pada sisi barat. Pada entrance ini terdapat buffer berupa pohon dan vegetasi sebagai taman semu agar site menjadi asri dan menarik untuk dikunjungi. Terdapat tangga-tangga dan area komunal outdoor dibagian ini sebagai area pengikat pertama kali bagi para pengunjung untuk saling berinteraksi dan berkumpul. 

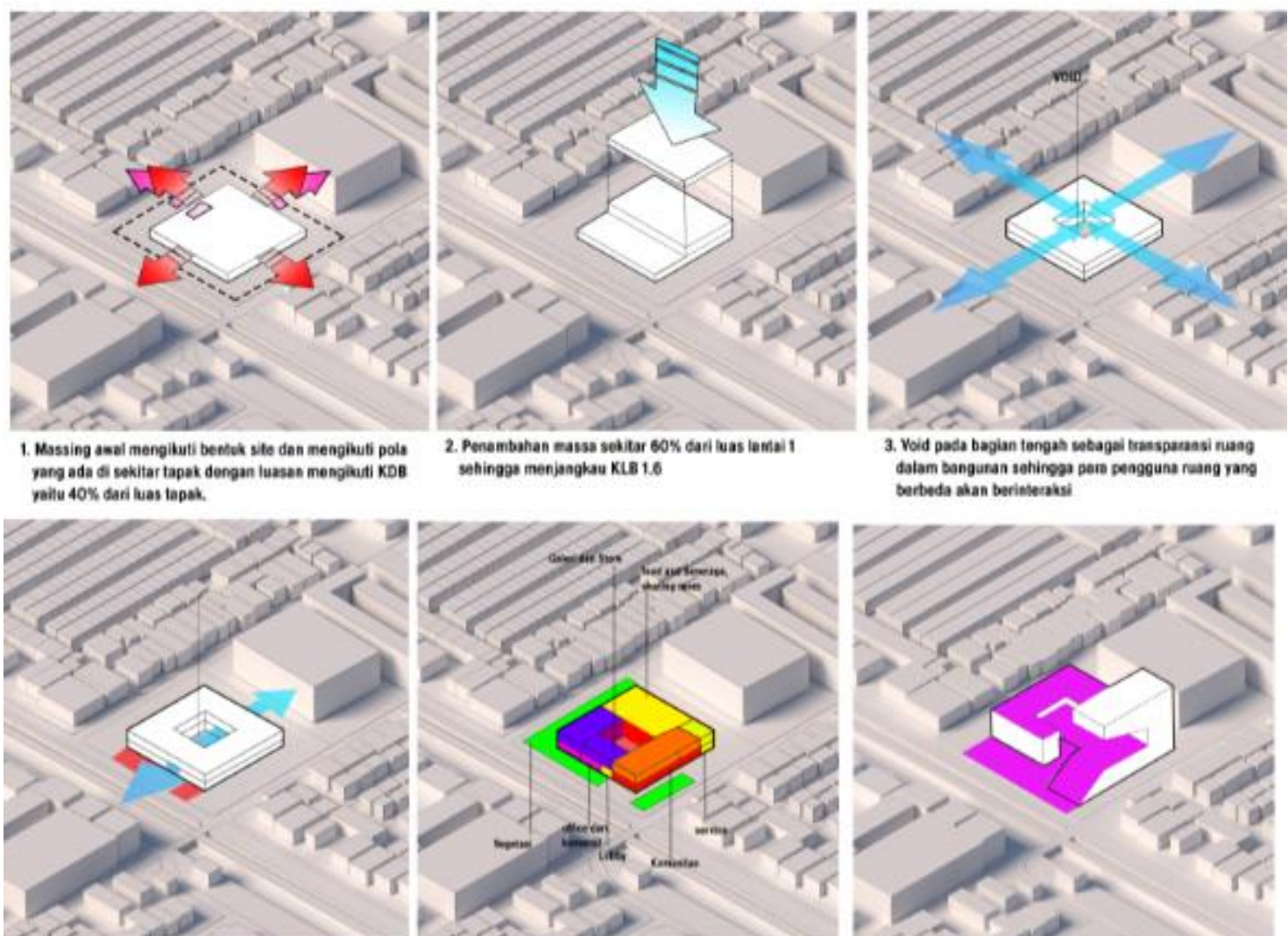

4. Linkage dengan gor dengas membuka sirkulasi lurus he arah datangevas pedestrian serta menpodiakan ruang kemunal poda bagian depan

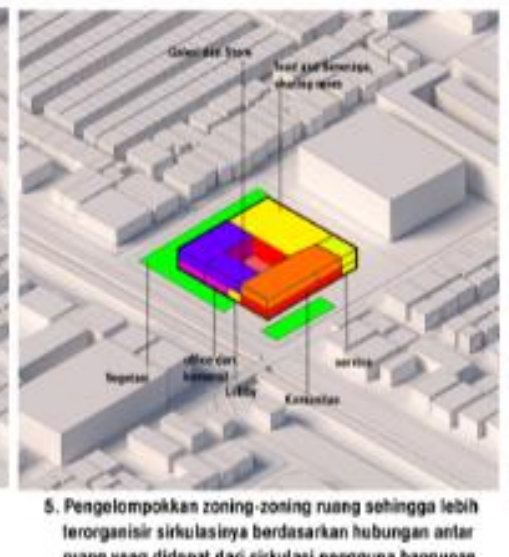

ruang yaag didapat dari sirkulasi pergguna bangunan

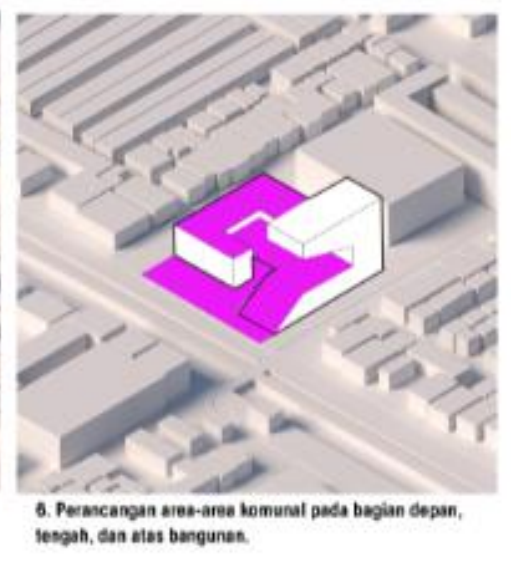

Gambar 7. Proses Gubahan Massa

Sumber : Penulis, 2019

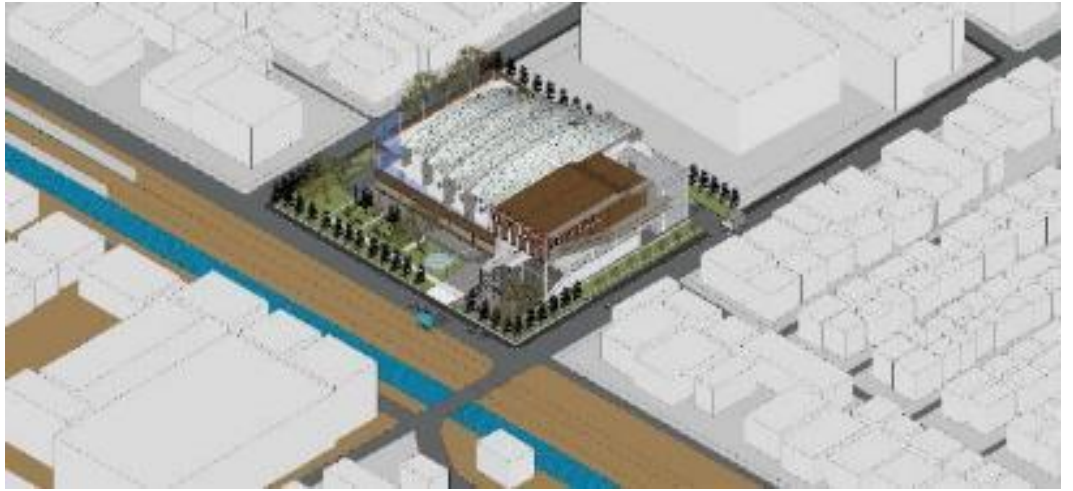

Gambar 8. Massa Bangunan

Sumber : Penulis, 2019

Proses gubahan masa terbentuk dengan melihat kawasan sekitar yang memiliki bentuk masa kotak sehingga bentuk bangunan ini juga mengikuti kawasan yaitu kotak agar tidak terlalu asing bagi kawasan sebagai bangunan baru. Lalu diolah dengan memasukkan program sehingga luasan yang dikehendaki menjadi optimal. Kemudian diolah dengan desain centris yaitu pengadaan ruang-ruang komunal terutama pada bagian tengah bangunan sebagai komunal utama yang dikelilingi oleh ruangan lainnya. Kemudian bagian teater musiknya dinaikkan sebagai pengadaan ruang komunal yang menarik sehingga dapat digunakan sebagai entrance pedestrian untuk masuk ke dalam bangunan (proses massing tahap 6). 


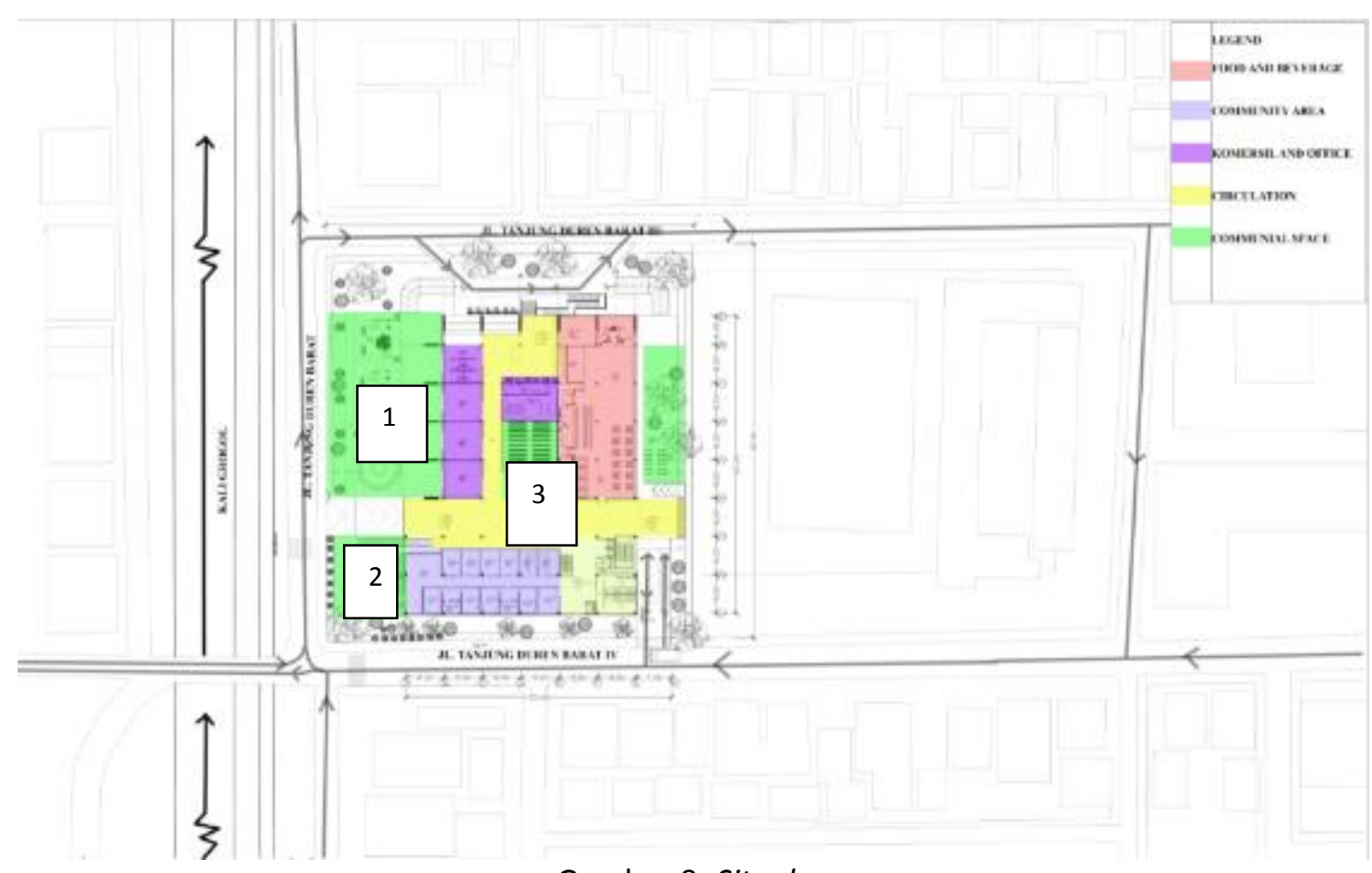

Gambar 9. Siteplan

Sumber : Penulis, 2019

Pengadaan ruang-ruang komunal dapat dilihat dari akses pedestrian di sebelah barat yang berwarna hijau dan berupa taman sebagai penarik perhatian dan juga area hijau dan juga buffer kebisingan dengan jalan raya. Area taman yang dirancang merupakan sebuah penarik perhatian bagi pengunjung dan juga kawasan. Taman ini digunakan sebagai area berkumpul baik itu untuk refreshing sore-sore atau pagi-pagi untuk duduk-duduk menghirup udara segar dari pepohonan taman ini. Taman ini sebagai third place terbuka yang mengikat orang-orang yang datang untuk berkumpul dan berinteraksi baik secara langsung atau hanya bertatap muka juga sudah menghilangkan aspek kemonotonan.

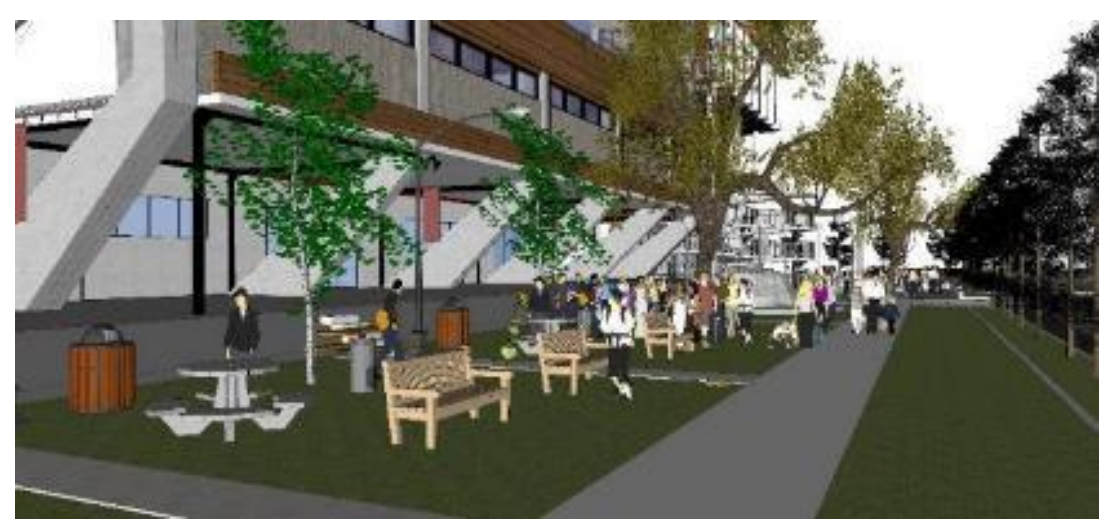

Gambar 10. Pengadaan Taman sebagai presensi ruang third place (no 1 gambar 9) Sumber : Penulis, 2019 


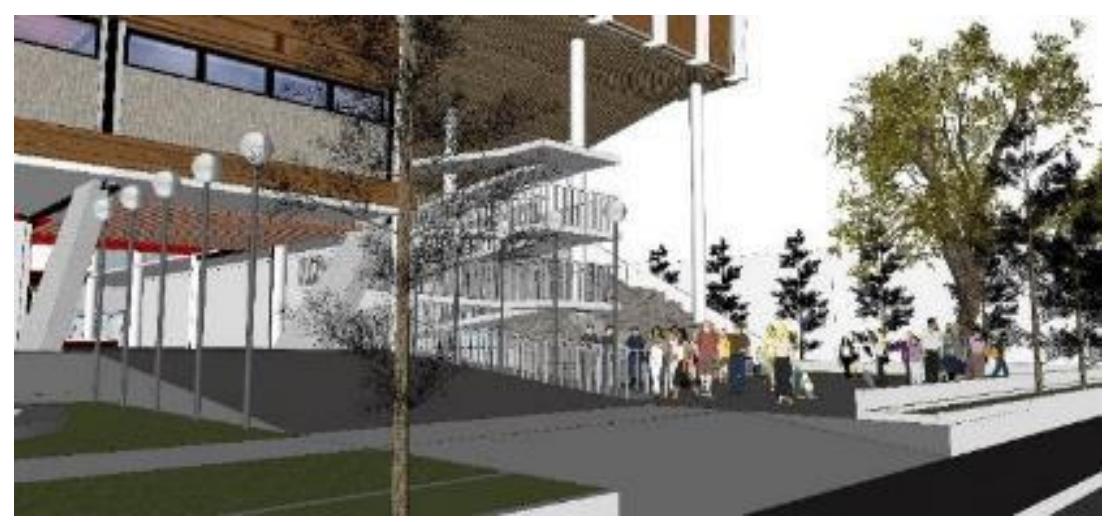

Gambar 11. Pengadaan Event Space sebagai presensi ruang third place

Sumber : Penulis, 2019

Pengadaan ruang event space pada bagian barat bangunan pada area entrance utama sebagai tempat third place pengikat utama dimana pada area ini menjadi area yang dapat digunakan untuk berbagai event seperti pertunjukkan musik dengan penggunaan tanggatangga sebagai tempat duduk untuk menonton. Pada area ini juga sebagai area pengikat dan area keramaian yang utama dari bangunan ini karena berada pada sisi terluar tapak dan dekat dengan entrance utama sehingga dapat menjadi daya tarik orang untuk berkunjung dan berbagai orang akan saling bertemu dan bertatap muka sehingga menghilangkan suasana yang monoton.

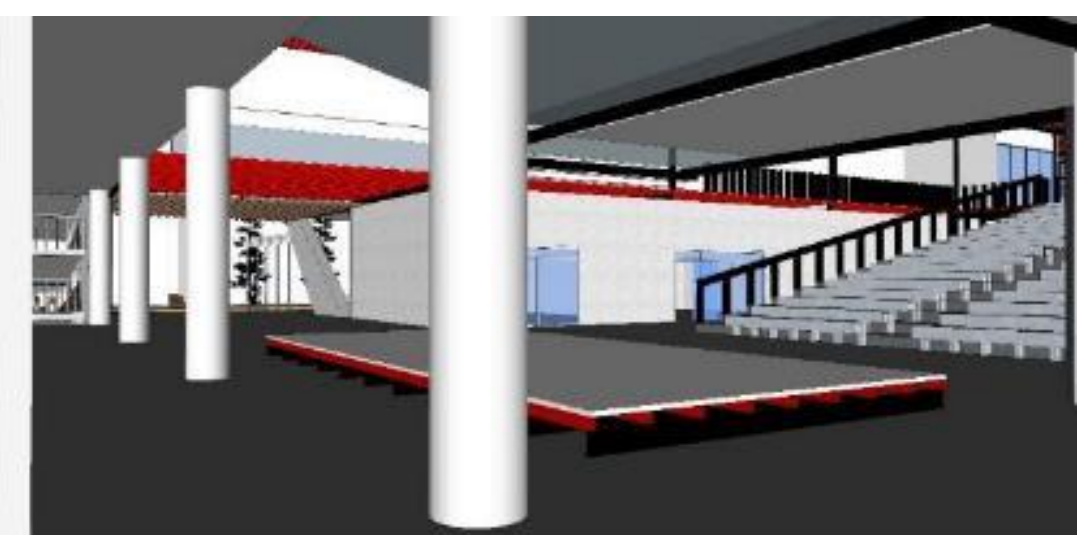

Gambar 12. Pengadaan Venue semi open auditorium sebagai presensi ruang third place dan koneksi ke lantai 2 (no 3 gambar 9)

Sumber : Penulis, 2019

Pengadaan venue sebagai semi open auditorium menjadi ruang komunal sebagai sebuah ruang third place dimana area ini merupakan area tempat kumpul pengunjung yang beragam juga. Dengan adanya tempat duduk untuk sekedar duduk melamun ataupun melihat sekeliling, area ini merupakan salah satu presensi third place yang menjadi pengikat para pengunjung. Alasannya karena keterbukaan dan merupakan salah satu akses untuk menuju lantai selanjutnya sehingga arah pergerakan pengunjung memusat melalui area ini. 


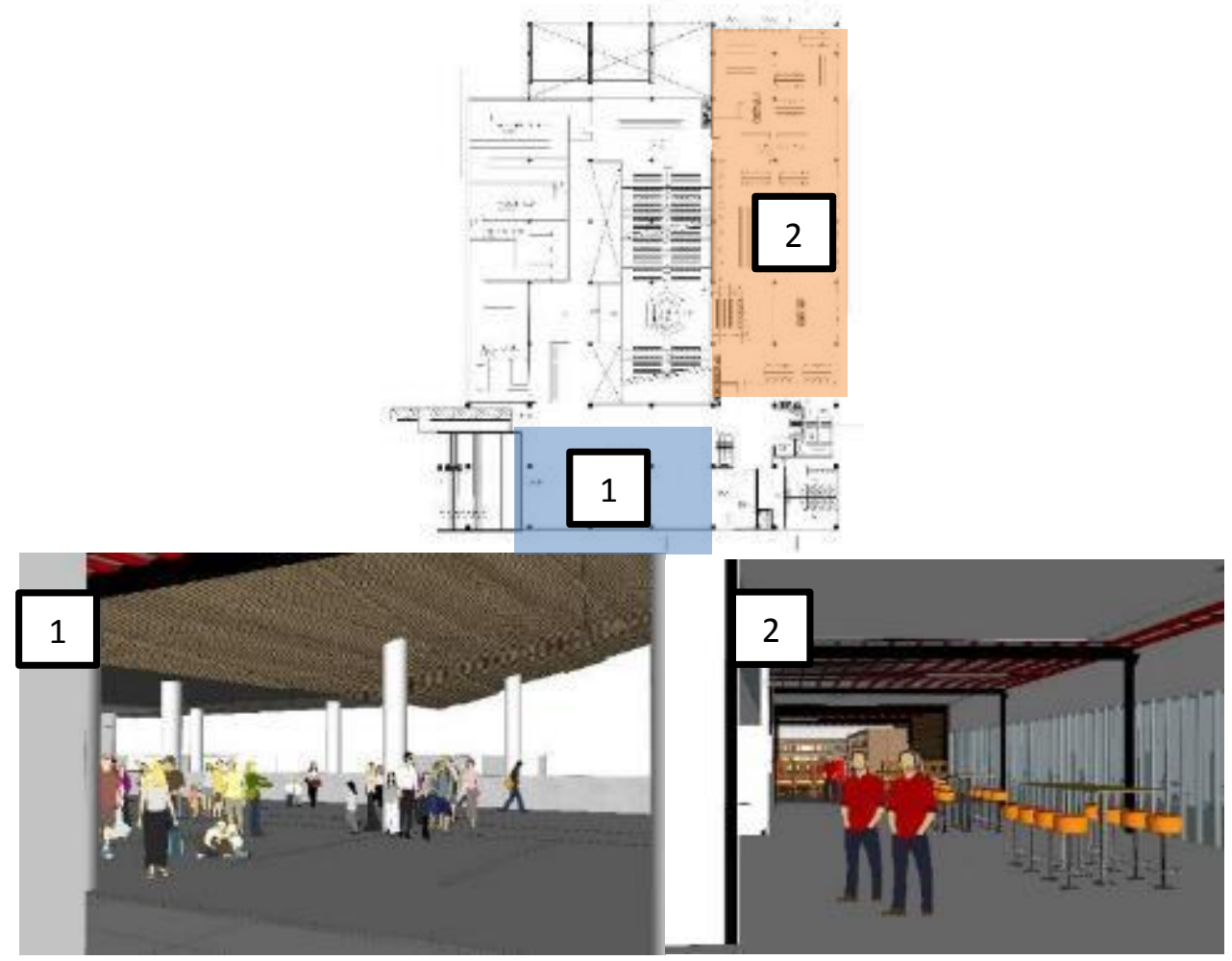

Gambar 13. Lantai 2 dan Visualisasi Ruangan third place

Sumber : Penulis, 2019

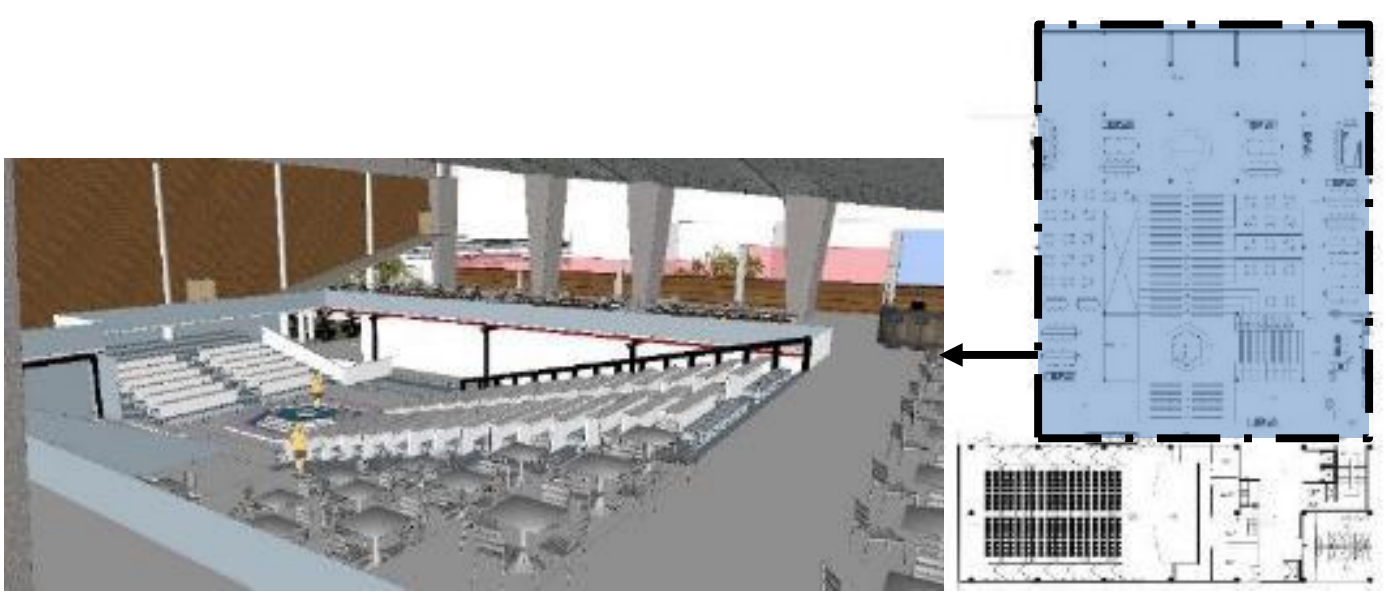

Gambar 14. Lantai 3 dan Visualisasi Ruangan Open Resto sebagai third place Sumber : Penulis, 2019

Perancangan third place selanjutnya terdapat di lantai 2 dan lantai 3 bangunan Musicarium ini. Pada lantai 2 ini terdapat temporary exhibition hall (lihat no 1 gambar 15) dimana para pengunjung dapat berkumpul untuk melihat galeri temporer di area tersebut. Terdapat juga sharing room yang terdapat perpustakaan, listening room, dan ruang kerja yang digabung menjadi satu ruang (lihat no 2 gambar 15). Pada lantai 3 terdapat open resto yang merupakan presensi third place yang memadukan panggung pertunjukkan musik secara langsung dengan tempat makan dan minum dengan orientasi ke arah panggung. Ketiga ruangan ini merupakan visualisasi third place dimana merupakan area berkumpulnya berbagai orang. 


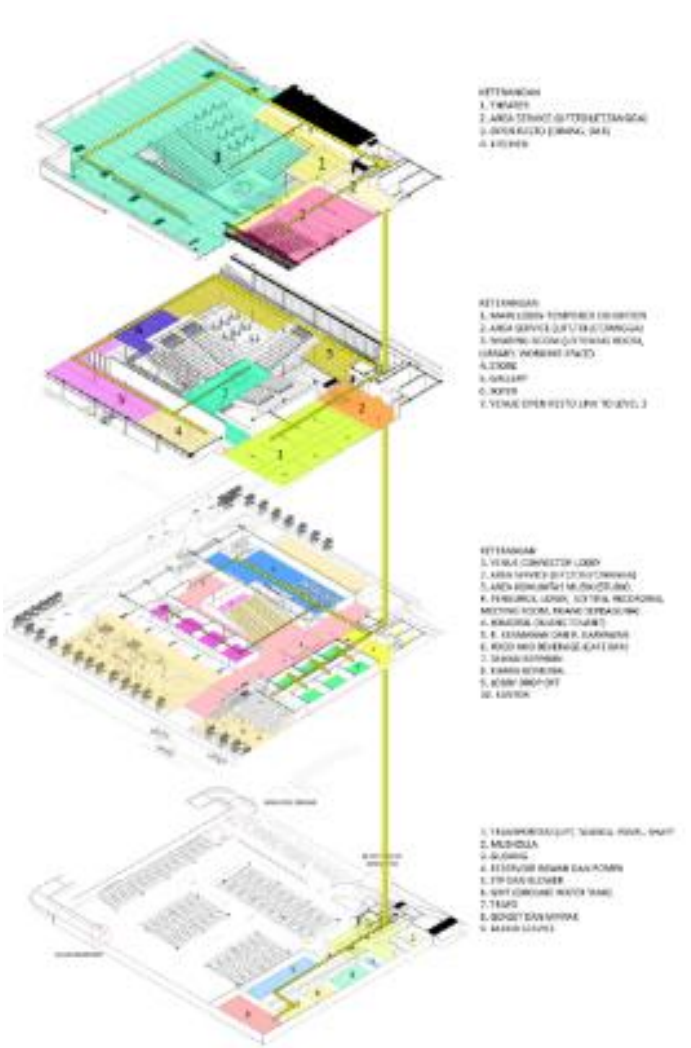

Gambar 15. Exploded Denah Sumber : Penulis, 2019
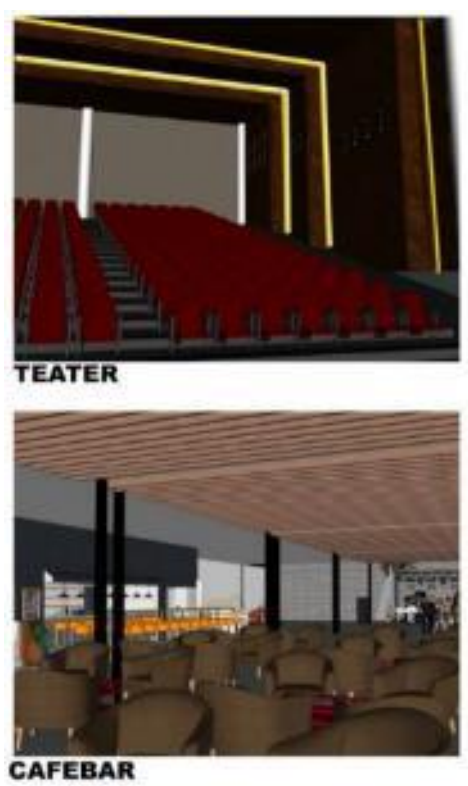

Gambar 17. Teater dan Cafebar Sumber : Penulis, 2019
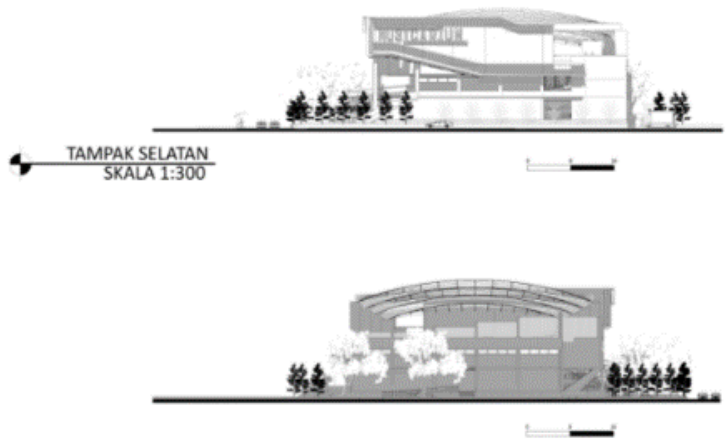

2. TAMPAK UTARA

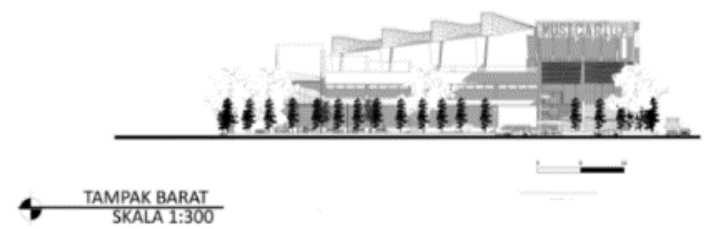

Gambar 16. Tampak Bangunan Sumber : Penulis, 2019

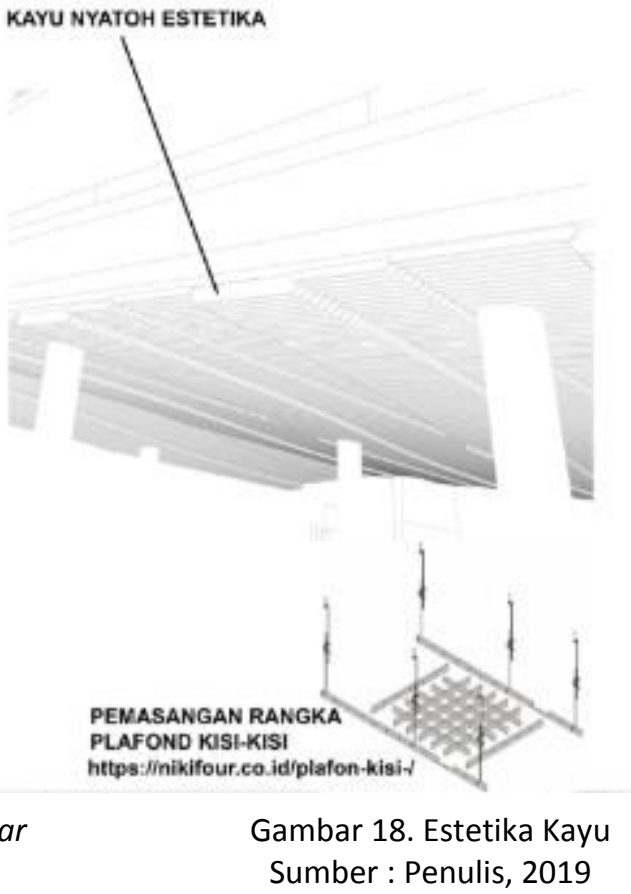




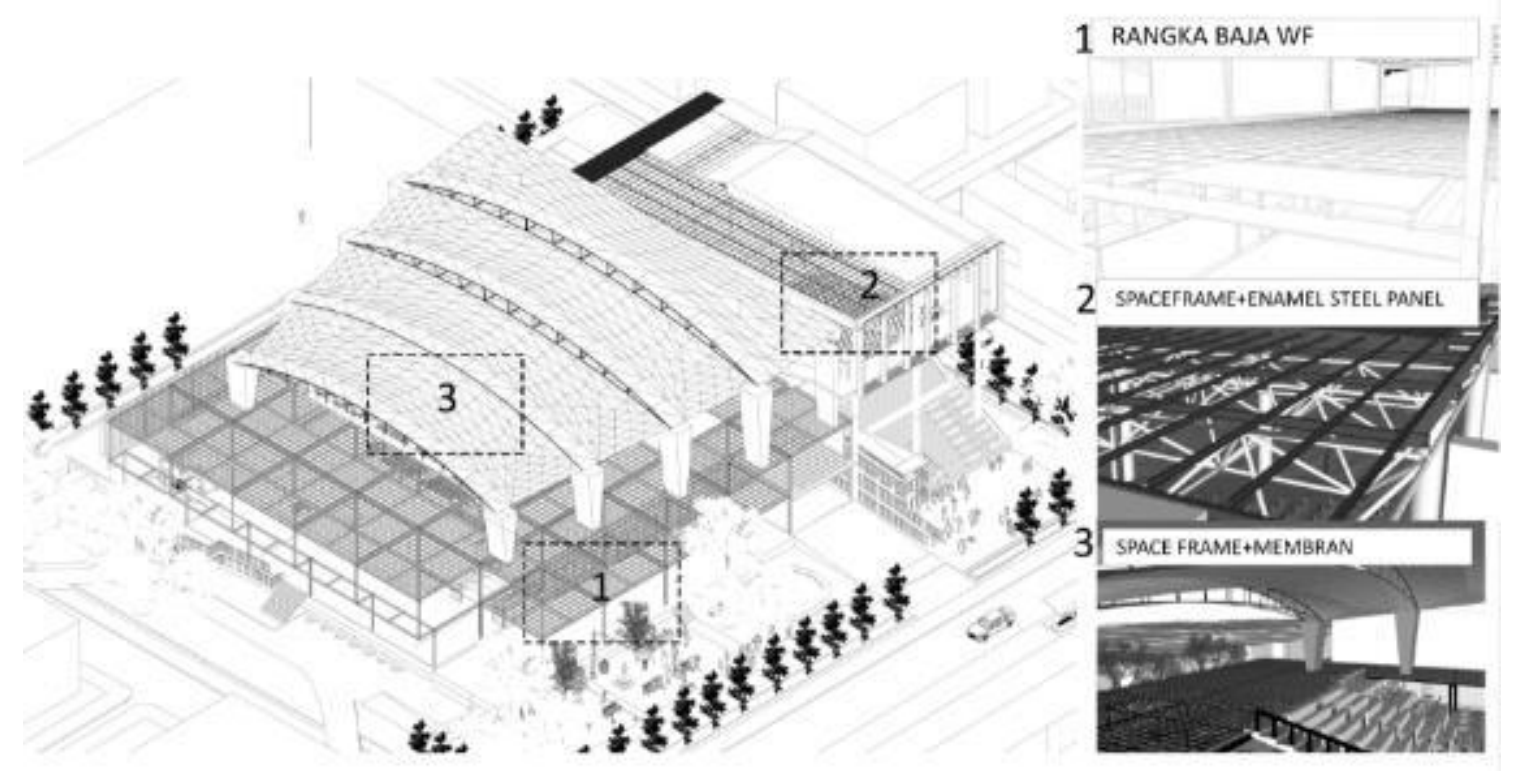

Gambar 19. Struktur

Sumber : Penulis, 2019

Penggunaan bahan struktur baja WF dan juga penggunaan space frame pada bangunan agar tidak terlalu berat dan masif. Penggunaan membran juga untuk sebagai atap dari open resto yang sifatnya semi outdoor.

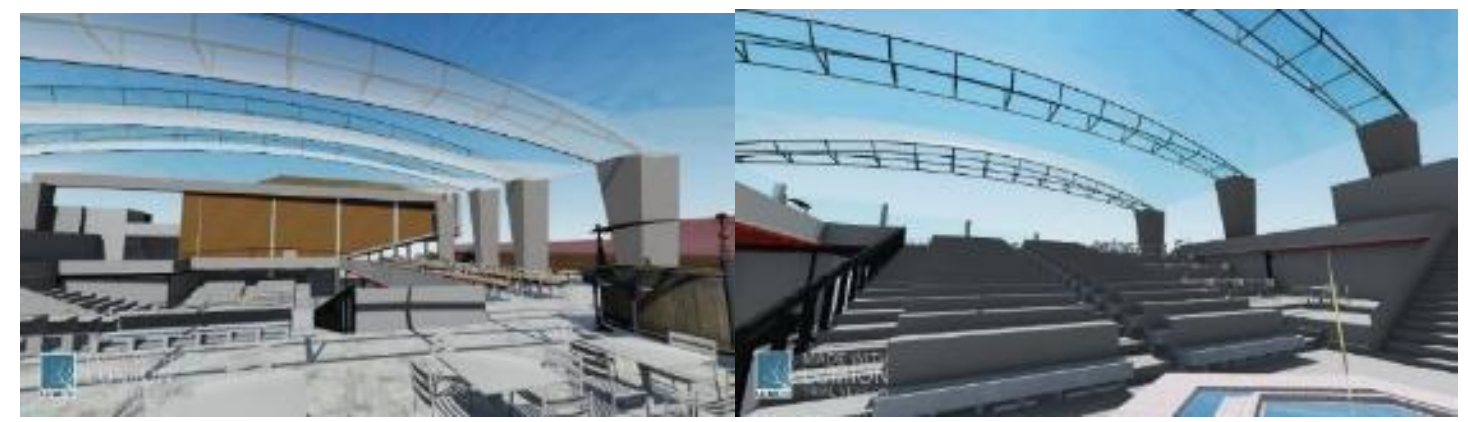

Gambar 20. Open Resto

Sumber : Penulis, 2019

Open resto yang berada dilantai paling atas pada bagian tengah bangunan merupakan salah satu program utama yang menyajikan sebuah ruang kumpul dimana pengunjung dapat duduk sambil minum ataupun makan dengan mendengarkan live music yang panggungnya berada di tengah-tengah mereka karena posisi orientasi tempat duduk diarahkan menuju panggung musik agar konsep sentris itu tetap ada dan juga pengunjung secara tidak langsung dapat bertatap muka dengan pengunjung lainnya dan hal tersebut memberikan efek warna secara tidak sengaja. 


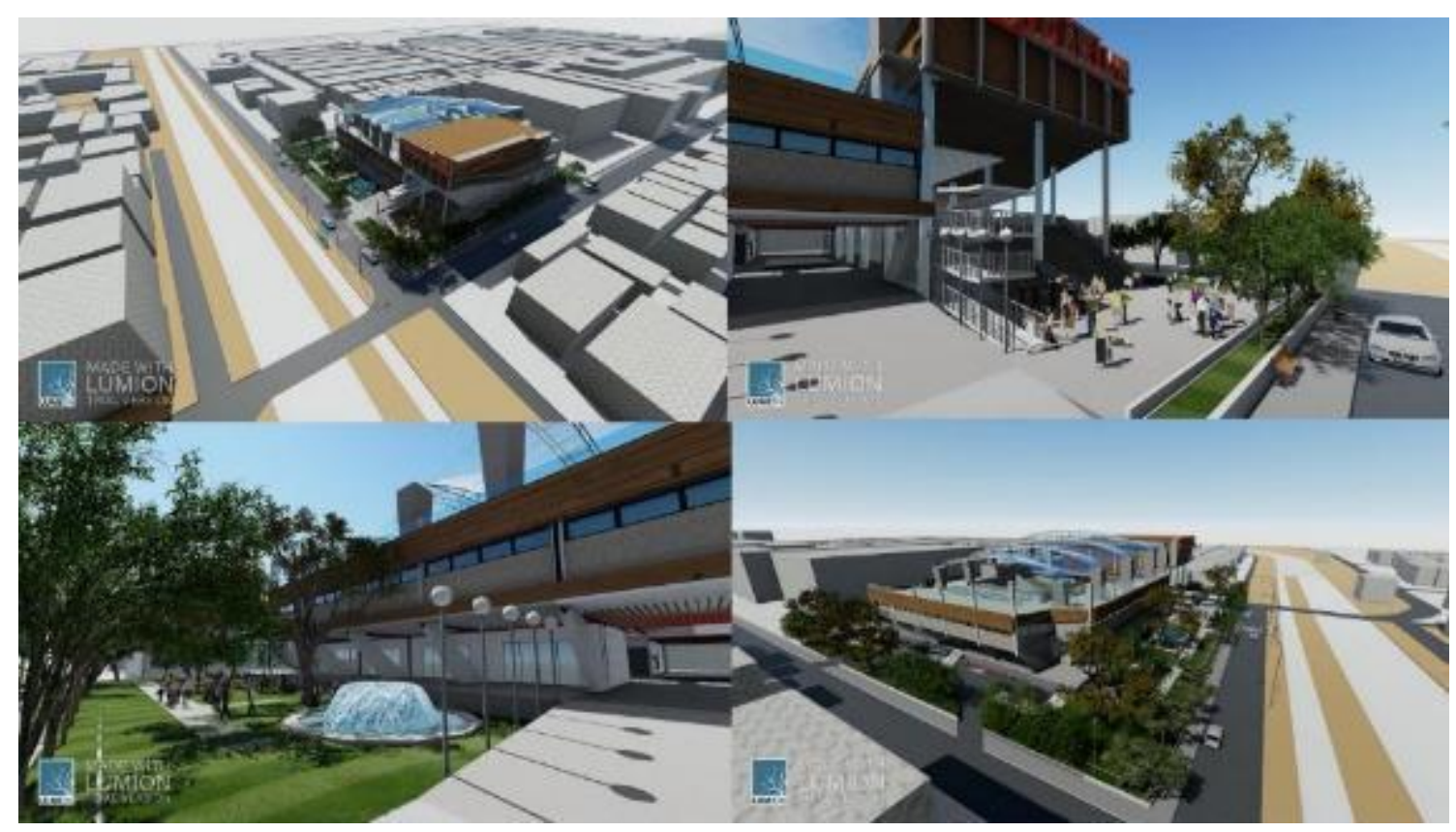

Gambar 21. Perspektif Eksterior

Sumber : Penulis, 2019

\section{KESIMPULAN}

Sekarang ini kebutuhan akan tempat berkumpul atau istilahnya "tongkrongan" sangat diperlukan bagi masyarakat kota. Kebutuhan akan rekreasi dalam mengisi leisure time menjadi kebutuhan dalam menghilangkan tingkat stress akibat rutinitas perkotaan yang monoton. $\mathrm{Di}$ kota Jakarta perlu untuk pengadaan tempat-tempat yang sifatnya rekreatif sehingga kepenatan masyarakat kota bisa hilang karena tempat berkumpul ini. Tempat berkumpul ini juga menjadi destinasi masyarakat kota untuk melepas kepenatan setelah bekerja dan mencari suasana yang menenangkan untuk bersantai dan berkumpul dengan orang-orang baru yang diluar dari rutinitasnya.

Rencananya tempat berkumpul ini akan ditempatkan di Tanjung Duren, Jakarta Barat yang dikenal sebagai destinasi kulinernya sehingga dapat menjadi tujuan untuk ngumpul dengan konsep penambahan musik yang langsung dari pemusik. Proyek ini mencoba untuk menyelesaikan permasalahan kota dengan melakukan pendekatan kepada kebutuhan akan leisure akan refreshing masyarakat kota yang kemudian dikembangkan melalui proses analisis data hingga mendapatkan program yang tepat dan sesuai untuk melepaskan kepenatan yaitu dengan ada unsur musik untuk merilekskan pikiran.

Dalam perancangan bangunan ini dilakukan berbagai analisis dengan lingkungan sekitar dalam memilih bentukan masa bangunan. Dalam perancangan dalam bangunan dirancang dengan konsep sentris dimana terdapat panggung utama bagi pemusik yang berada ditengah bangunan dan dikelilingi oleh tempat makan yang berorientasi ke panggung tersebut. Pada bangunan ini juga disediakan beberapa ruang komunal untuk titik temu dari para pengunjung sehingga sifatnya berkesan terbuka dan heterogen sehingga transparan.

\section{REFERENSI}

Hartoto, J. (1983). Peranan Rekreasi bagi Kehidupan Keluarga. Majalah. Yogyakarta: PPM IKIP Yogyakarta. Diperoleh dan diakses pada 27 Desember 2019. $<$ https://adoc.tips/queue/pemanfaatan-waktu-luang-mahasiswa-programstudlilmu-keolahra.html> 
Informasi 2018, 29 Desember. 5 Alasan Mengapa Live Music Penting untuk Kafe dan Restoran. Diperoleh dan diakses pada $27 \quad$ Desember 2019. $<$ https://mussy.co/blog/5_Alasan_Mengapa_Live_Music_Penting_Untuk_Kafe_dan_Restor an>

Jeffres, L. W., Cheryl C. B., Guoweijian, Mary F. C. (2009). The Impact of Third place on Community Quality of Life : base on Springer Science. Diakses pada 27 Desember dan diambil kembali dari jurnal online <https://www.researchgate.net/publication/226184181_The_Impact_of_Third_Places_on_ Community_Quality_of_Life

Kholid, D. M. (2016). PERANAN MUSIK PADA PERTUNJUKKAN TEATER. Bandung : Universitas Pendidikan Indonesia. Diakses pada 27 Desember 2019. <https://ejournal.upi.edu/index.php/ritme/article/download/5076/3537>

Kurniawan, M. L. (2017). Gedung Pertunjukan Musik di Makassar. Makasar : Universitas Hasanuddin. Diakses pada $28 \quad$ Desember 2019. $<$ http://digilib.unhas.ac.id/uploaded_files/temporary/DigitalCollection/ZTFiMGQyZjQxYmlx Yjk1MzhiM2QwMGIOZDVkYTNiNjRhZWUOMjdkNQ==.pdf>

Oldenburg, R. (1989). The Great Good Place: Cafes, Coffee Shops, Bookstores, Bars, Hair Salons, and Other Hangouts at the Heart of a Community. USA: Marlowe \& Company.

Purnomo, N. A. (2000). Kafe Musik di Semarang. Semarang : Universitas Diponegoro. Diakses 28 Desember 2019. <http://eprints.undip.ac.id/24549/1/kafe_musik_di_semarang.pdf>

Sidiq, S., dkk (2016). Gedung Pertunjukan Seni. Diponegoro University Institutional Repository ISBN 2102011213004. Diambil dari $<$ https://onesearch.id/Record/IOS2852.49740\#holdings

Suwardi, A.L (2003). Isu dan Kreativitas Seni. Makalah Seminar Seni Pertunjukkan Indonesia, $\begin{array}{lllll}\text { Surakarta. } & \text { Diakses } & \text { pada } & 27 & \text { Desember }\end{array}$ <https://studylibid.com/doc/2298149/peranan-musik-pada-pertunjukkan-teater>

Tjahjono, G (2000). Metode Rerancangan Suatu Pengantar untuk Arsitek dan Perancang. Jakarta: Universitas Indonesia 
